\title{
Peningkatan Keaktifan Mahasiswa pada Perkuliahan Sejarah dan Filsafat Matematika melalui Model Pembelajaran Auditory Intellectually Repetition
}

\author{
Rani Sugiarni ${ }^{1}$, Ayuni Rizka Ifanda ${ }^{2}$ \\ 1,2 Pendidikan Matematika, FKIP, Universitas Suryakancana \\ *rani@unsur.ac.id \\ \begin{tabular}{|l|l|l|}
\hline Received : $31-7-2018$ & Revised: $4-2-2020$ & Accepted: $18-2-2020$ \\
\hline
\end{tabular}
}

\begin{abstract}
ABSTRAK
Keatifan mahasiswa dalam perkuliahan biasanya bergantung pada dosen memberikan metode pembelajaran dikelasnya. Metode yang berpusat pada dosen biasanya yang memposisikan mahasiswa sebagai objek didik (menganggap mahasiswa sebagai botol kosong yang siap diisi) perlu segera ditinggalkan dan diubah ke arah metode yang berpusat pada mahasiswa, yaitu dengan model pembelajaran yang memposisikan mahasiswa sebagai subyek didik yang secara aktif terlibat dalam proses pembelajaran, baik secara fisik, mental, maupun emosinya dan mahasiswa semua terlibat dalam setiap pertemuannya. Terbukti perkuliahan sebelumnya hanya $22 \%$ mahasiswa yang terlibat aktif dalam kelas pada mata kuliah teori. Salah satu alternatif untuk meningkatkan keaktifan mahasiswa yaitu dengan menggunakan model pembelajaran Auditory Intellectually Repetition (AIR). Metode penelitian menggunakan metode penelitian tindakan (PTK). Pada penelitian ini, subjeknya adalah mahasiswa Program Studi Pendidikan Matematika Universitas Suryakancana tingkat I semester 2 tahun akademik 2016-2017 pada mata kuliah Sejarah dan Filsafat Matematika. Teknik Pengumpulan data menggunakan instrument non tes yakni menggunakan lembar observasi. Berdasarkan hasil analisis observasi yang diuraikan dapat disimpulkan bahwa model pembelajaran Auditory Intellectually Repetition (AIR) pada mata kuliah Sejarah dan Filsafat Matematika dapat meningkatkan keaktifan mahasiswa selama perkuliahan berlangsung.
\end{abstract}

Kata kunci : Auditory Intellectually Repetition, Keaktifan, PTK

\begin{abstract}
A lecturer-centered learning approach that positions the students as the students' objects (students as empty bottles that are ready to fill) needs to be quickly abandoned and transformed into a student-centered approach, ie a learning approach positioning students as subjects who are actively involved in the process Learning, both physically, mentally, and emotionally and students are all involved in every encounter. Proven lectures previously only $22 \%$ of students who are actively involved in the class on the theory course. One of the alternatives to improve student activeness is by using Auditory Intellectually Repetition (AIR) learning model. The research method uses action research method (PTK). In this study, the subject is a student of Mathematics Education Study Program of Universitas Suryakancana I semester 2 academic year 2016-2017 in History and Philosophy of Mathematics course. Technique Data collecting is done by using non test instrument that is using observation sheet. Based on the result of the observation analysis, it can be concluded that the learning model of Auditory Intellectually Repetition (AIR) in History and Philosophy of Mathematics Course can improve students' activity during the lecture.
\end{abstract}

Keywords: Auditory Intellectually Repetition, Activity, ACM 


\section{PENDAHULUAN}

Proses pembelajaran mahasiwa yang diatur pada Peraturan Menteri Riset, Teknologi, Dan Pendidikan Tinggi Republik Indonesia nomor 44 tahun 2015 Pasal 10 ayat (2) mengharuskan mahasiswa untuk bersifat interaktif, holistik, integratif, saintifik, kontekstual, tematik, efektif, kolaboratif, dan berpusat pada mahasiswa (Norjannah, 2015). Agar hal tersebut di atas dapat terwujud, dosen seyogyanya mengetahui bagaimana cara mahasiswa belajar dan menguasai berbagai cara membelajarkan mahasiswanya Dengan kata lain, dosen perlu mengetahui berbagai meode dan model belajar yang membahas bagaimana cara mahasiswa aktif selama perkuliahan, dan menguasai berbagai metode dan model pembelajaran yang membahas tentang bagaimana cara membelajarkan mahasiswa dengan berbagai variasinya, sehingga terhindar dari rasa bosan. Namun sayangnya, bentuk pembelajaran di perguruan tinggi saat ini masih cenderung dominan menggunakan metode lama yakni ceramah (Septian, 2017). Dalam metode ceramah strategi bahan pelajaran disajikan kepada mahasiswa dalam bentuk jadi dan peserta didik dituntut untuk mendengarkan dan menguasai bahan tersebut. Dari segi dosen, metode ini sering disebut sebagai strategi ekspositori karena dosen cenderung berfungsi sebagai penyampai pesan atau informasi belajar (Sanjaya, 2010). Pada strategi pembelajaran ekspositori ini, mahasiswa cenderung hanya dipandang sebagai obyek didik yang bersifat pasif yang siap menerima materi dari dosen.

Ada temuan menurut para ahli dalam memperkuat kesimpulan tersebut. Seperti (Dimyati, 2013), pembelajaran mahasiswa di Indonesia rendah dalam kemampuan membaca, menulis, memikir, observasi, ekspresi estetis, etis, epistemis, teknologis dan teologi. Selain itu, menyatakan bahwa telah terjadi formalisasi proses pembelajaran di perguruan tinggi. Peran utama dikelas didominasi oleh dosen yang berperan menyajikan, menjelaskan, menganalisis dan mempertanggungjawabkan kuliah. Sedangkan mahasiswa mendengarkan dan menghafal bahan kuliah yang disampaikan oleh dosen untuk menjadi bahan ujian. Peranan yang didominasi oleh dosen yang berlangsung satu arah dalam proses perkuliahan berdampak pada keatifan mahasiswa yang rendah. Hal ini kurangnya kesempatan mahasiswa dalam perkuliahan untuk terlibat aktif. Keberanian mahasiswa untuk bertanya, mengajukan pendapat, berdiskusi sepertinya telah "terpasungee oleh tradisi dosen yang mendominasi perkuliahan. Mata kuliah filsafat dan sejarah matematika yang menjadi dasar mereka untuk berpikir filsafat cendrung pasif hanya mengandalakan kelompok yang presentasi dan sebagian mendengarkan. Dengan demikian, metode ceramah atau pembelajaran yang berpusat pada dosen perlu segera ditinggalkan dan diubah 
ke arah model pembelajaran yang berpusat pada mahasiswa, yaitu model pembelajaran yang memposisikan mahasiswa sebagai subyek didik yang secara aktif terlibat dalam proses pembelajaran, baik secara fisik, mental, maupun emosinya dan mahasiswa semua terlibat dalam setiap pertemuannya (Inayah, Septian, \& Suwarman, 2020; Maskur et al., 2020). Hal ini terbukti perkuliahan sebelumnya hanya $22 \%$ mahasiswa yang terlibat aktif dalam kelas pada mata kuliah teori dengan metode ceramah

Salah satu upaya hal tersebut yaitu dengan pembelajaran Auditory, Intellectually, Repetition atau sering disingkat AIR. Hasil penelitian bahwa model pembelajaran AIR dapat meningkatkan keaktifan dalam proses pembelajaran (Agustiana, Putra, \& Farida, 2018).

Pembelajaran AIR ini lebih dikenal dengan pendekatan kontruktivisme dimana pembelajarnnya memanfaatkan hampir semua panca indra selama proses pembelajaran sehingga mahasiswa akan melibatkan semua panca indranya dalam pembelajaran seperti pendengaran, berpikir dan pengulangan.

Keaktifan berasal dari kata aktif artinya giat bekerja, giat berusaha, bereaksi maupun beraksi, sedangkan keaktifan adalah kesibukan atau kegiatan. Dalam proses perkuliahan keaktifan sangat diperlukan mahasiwa, sebab prinsipnya keatifan melatih bagaimana berbuat untuk mendapat pengetahuan. Keaktifan sangat diperlukan terutama untuk calon guru mataematika yang nantinya melatih dalam kemampuan keprofsional sebagai seorang guru.

Menurut (Hamalik, 2011) keaktifan belajar dikelompokan sebagai berikut: (1) Kegiatan-kegiatan visual, Kegiatan visual berhubungan dengan indra penglihatan seperti membaca, melihat gambar, mengamati, demontrasi, pameran dan lain-lain; (2) Kegiatankegiatan lisan, Kegiatan lisan berhubungan dengan indra ucap seperti mengemukakan suatu fakta atau prinsip, menghubungkan tujuan, mengajukan suatu pertanyaan, memberi saran, mengemukakan pendapat, wawancara, diskusi dan interupsi; (3) Kegiatan-kegiatan mendengarkan, Kegiatan berhubungan dengan indra pendengaran anatara lain mendengarkan penyajian bahan, mendengar percakapan atau diskusi kelompok, mendengarkan radio atau suara-suara; (4) Kegiatan-kegiatan menulis, Kegiatan yang menggunkan alat tulis seperti menulis cerita, menulis laporan, menulis karangan, membuat rangkuman, mengerjakan tes atau isi angket.; (5) Kegiatan-kegiatan menggambar, Kegiatan menggambar biasanya meliputi menggambar, membuat grafik, chart, diagram, peta dan pola; (6) Kegiatan-kegiatan metrik, Kegiatan ini meliputi melakukan percobaan, memilih alat-alat, melakukan pameran, menari dan berkebun.; (7) Kegiatan-kegiatan 
mental, Kegiatan mental merupakan merenugkan, mengingatkan, memecahkan masalah, menganalisa faktor-faktor, melihat hubungan-hubungan dan membuat keputusan; (8) Kegiatan-kegiatan emosional, Kegiatan emosional meliputi minat, mebedakan, berani, tenang dan lainnya.

Menurut (Sutarno, Rohendi, \& Putri, 2011) Auditory Intellectually Repetition ( AIR ) adalah model pembelajaran dimana guru/dosen sebagai fasilitator dan siswalah/ mahasiswalah yang lebih aktif. Sejalan dengan pendapat Dedi Rohendi, Heri Sutarno, Lies Puji Lestari mendasari untuk meningkatkan keaktifan mahasiswa dengan model pembelajaran AIR dengan mewujudkan proses pembelajaran sesuai dengan Peraturan Menteri Riset, Teknologi, Dan Pendidikan Tinggi Republik Indonesia Tahun 2015.

Model pembelajaran Auditory Intellectually Repetition (AIR) merupakan model pembelajaran yang hampir sama dengan model pembelajaran Visualization Auditory Kinesthetic (VAK) dan Somatic Auditory Visualization Intellectually ( SAVI). Namun perbedaannya hanya pada pendalaman, perluasan dan pemantapan untuk mahasiswa yang dilatih dalam hal ini diberi kuis atau tugas.

Tahapan pada model pembelajaran AIR dalam (Isna \& Masykuri, 2018) adalah: (1) Fase pertama, Auditory yaitu indra telinga digunakan dalam belajar dengan cara mendengarkan, menyimak, berbicara, mengemukan pendapat, menanggapi, presentasi dan argumentasi; (2) Fase kedua, Intellectually yaitu kemampuan berpikir dilatih melalui latihan bernalar, mengkontruksi, menerapkan gagasan, mengajukan pertanyaan, dan menyelesaikan masalah; (3) Fase ketiga, Repetition, dosen bersama-sama dengan mahasiswa melakukan pengulangan materi melalui kuis, tugas pekerjaan rumah agar pemahaman mahasiswa lebih luas dan mendalam.

\section{METODE PENELITIAN}

Metode penelitian yang digunakan yaitu penelitian tindakan kelas dalam rangka memperbaiki keaktifan mahasiswa selama proses perkuliahan melalui model pembelajaran Auditory Intellectually Repetition (AIR). Penelitian ini dilaksanakan pada semester genap tahun ajaran 2016/2017. Subjek dalam penelitian ini tingkat 1 program studi pendidikan matematika pada mata kuliah filsafat dan sejarah matematika di Universitas Suryakancana.

Kegiatan penelitian ini dilaksanakan dalam tiga siklus. Daur ulang dalam penelitian tindakan diawali dengan perencanaan tindakan (Planning), tindakan pelaksanaan (action), observasi (observation), refleksi (reflection) dan seterusnya sampai perbaikan atau peningkatan yang diharapkan tercapai (kriteria keberhasilan) (Arikunto, 2006). 
Alur penelitian tindakan kelas menunjukan daur ulang dari setiap siklus penelitian yang dilakukan dimana tahapan-tahapan pada setiap siklusnya adalah sebagai berikut : (1) Rencana, Pelaksanaannya, rencana berupa persiapan pembuatan instrument non tes, dengan menggunakan lembar observasi mahasiswa; (2) Tindakan, Tahap tindakan ini dilaksanakan dalam bentuk proses perkuliahan sesuai dengan perencanaan yang telah disusun. Tindakan observasi tersebut dilaksanakan pada setiap siklus. Tindakan siklus kedua langkah perbaikan dari siklus pertama dan tindakan siklus ketiga sebagai perbaikan dari siklus kedua dan seterusnya.

Tindakan yang sudah dilaksanakan dapat diuraikan sebagai berikut : (a) Penjelasan penggunaan lembar observasi keaktifan; (b) Pelaksanaan perkuliahan dengan model pembelajaran Auditory Intellectually Repetition (AIR); (c) Observasi keaktifan mahasiswa selama berlangsungnya perkuliahan (3) Refleksi, Refleksi merupakan langkah yang dilaksanakan untuk mengkaji ulang setiap tindakan perkuliahan yang telah berlangsung. Refleksi tindakan dilakuakan oleh dosen dan mahasiwa, didasarkan pada hasil observasi mahasiswa.

Hasil refleksi pertama menjadi dasar untuk rencana dan tindakan siklus kedua, sedangkan hasil refleksi siklus kedua menjadi dasar untuk rencana dan tindakan siklus ketiga dan seterusnya. Adapun langkah dalam refleksi tindakan meliputi tahap : a) identifikasi aktivitas yang telah dilakukan selama kegiatan perkuliahan berlangsung pada setiap siklus; b) analisis data hasil refleksi dan rincian tindakan perkuliahan yang telah dilaksanakan; c) rumusan solusi untuk tindakan selanjutnya berdasarkan hasil analisis kegiatan refleksi yang dilakukan secara berkelompok antara peneliti dengan guru bidang studi.

Teknik pengambilan data keaktifan mahasiwa dalam pembelajaran diperolehdengan metode observasi. Metode observasi menurut (Suharsimi, 2013) merupakan metode yang paling efektif dengan melengkapinya dengan format atau blanko pengamatan sebagai instrumen. Metode observasi digunakan untuk mengumpulkan data mengenai aktivitas mahasiswa, dalam hal ini keaktifan mahasiswa selama proses perkuliahan berlangsung dengan model pembelajaran AIR. 


\section{HASIL DAN PEMBAHASAN}

Untuk mengetahui keberhasilan penelitian dan kontribusi pembelajaran dengan menggunakan model pembelajaran AIR terhadap peningkatan keaktifan mahasiswa maka dilakukan analisis tingkat keaktifan dalam perkulihan yang dilaksanakan pada setiap siklus. Dari hasi analisis diperoleh hasil observasi setiap siklus yang dilaksanakan setiap pertemuannya.

\section{Tingkat Keaktifan Ditinjau Dari Auditory Secara Keseluruhan}

Dari hasil analisis tingkat kekatifan mahasiswa secara keseluluhan setiap siklus, maka di analisis tingkat keaktifan mahasiswa secara keseluruhan setiap siklusnya. yang hasilnya terangkum dalam tabel sebagai berikut:

Tabel 1. Tingkat Keaktifan Mahasiswa Ditinjau Dari Auditory Secara Keseluruhan

\begin{tabular}{lcccccc}
\hline \multicolumn{1}{c}{ Siklus } & \multicolumn{2}{c}{ Siklus I } & \multicolumn{2}{c}{ Siklus II } & \multicolumn{2}{c}{ Siklus III } \\
\hline \multicolumn{1}{c}{ Pertemuan } & 1 & 2 & 3 & 4 & 5 & 6 \\
\hline Mendengarkan & $90 \%$ & $90 \%$ & $95 \%$ & $100 \%$ & $100 \%$ & $100 \%$ \\
\hline Menyimak & $80 \%$ & $85 \%$ & $90 \%$ & $90 \%$ & $90 \%$ & $100 \%$ \\
\hline $\begin{array}{l}\text { Presentasi Sesuai } \\
\text { Kelompok }\end{array}$ & 4 & 3 & 3 & 4 & 3 & 3 \\
\hline
\end{tabular}

Dilihat dari Tabel 1 terlihat tingkat keaktifan mahasiswa secara keseluluhan dilihat dari Auditory dalam hal mendengarkan mahasiswa secara keseluluhan siklus I rerata $90 \%$, siklus II 95\% dan siklus III sudah meningkat 100\% seluruhnya menggunakan indera pendengarannya, sedangkan untuk menyimak siklus I 80\%, Siklus II 90\% dan $95 \%$ siklus III sudah menyimak dengan baik. Sedangkan untuk presentasi semua hadir dan memprsentasikan sesuai dengan kelompoknya.

\section{Tingkat Keaktifan Ditinjau Dari Intellectualy Secara Keseluruhan}

Tabel 2. Tingkat Keaktifan Mahasiswa Ditinjau dari Intellectualy Secara Keseluruhan

\begin{tabular}{|c|c|c|c|c|c|c|c|}
\hline Siklus & \multicolumn{2}{|c|}{ Siklus I } & \multicolumn{2}{|c|}{ Siklus II } & \multicolumn{2}{|c|}{ Siklus III } & \multirow[t]{2}{*}{ TOTAL } \\
\hline Pertemuan & 1 & 2 & 3 & 4 & 5 & 6 & \\
\hline Menambahkan & 1 & 4 & 2 & 4 & 4 & 4 & 19 \\
\hline Bertanya & 3 & 3 & 3 & 3 & 3 & 3 & 18 \\
\hline Menjawab & 4 & 6 & 6 & 6 & 7 & 8 & 37 \\
\hline Jumlah & 8 & 13 & 11 & 13 & 14 & 15 & 74 \\
\hline Total & \multicolumn{2}{|c|}{21} & \multicolumn{2}{|c|}{24} & \multicolumn{2}{|c|}{29} & \\
\hline
\end{tabular}

Dilihat dari Tabel 2 terlihat tingkat keaktifan mahasiswa dilihat dari Intellectualy dalam hal menambahkan siklus I 21 orang, siklus II bertambah 24 dan meningkat di siklus 
III menjadi 29 orang hampir seluruh dikelas aktif dalam perkuliahan dalam hal menambahkan, bertanya dan menjawab. Pada saat proses perkuliahan mahasiswa tidak hanya aktif dalam menambahkan materi, bertanya dan menjawab pertanyaan, mahasiswa juga aktif dalam menyangga jawaban dari temannya yang tidak sependapat dengan jawaban mahasiswa.

\section{Tingkat Keaktifan Ditinjau Dari RepetitionSecara Keseluruhan}

Tabel 3. Tingkat Keaktifan Mahasiswa Ditinjau Dari Repetition Secara Keseluruhan

\begin{tabular}{cccccccc}
\hline Siklus & \multicolumn{2}{c}{ I } & \multicolumn{2}{c}{ II } & \multicolumn{2}{c}{ III } & Rerata \\
\cline { 1 - 6 } Pertemuan & 1 & 2 & 3 & 4 & 5 & 6 & \\
\cline { 1 - 6 } Rata-rata & 54 & 76 & 81 & 78 & 100 & 80 & 78 \\
\cline { 1 - 5 } Total rata-rata & 65 & \multicolumn{2}{c}{60} & \multicolumn{2}{c}{90} & & \\
\hline
\end{tabular}

Dilihat dari Tabel 3 terlihat tingkat keaktifan mahasiswa dilihat dari repetition dalam hal kuis rerata siklus I 65, bertambah pada siklus II 80, dan meningkat siklus III 90. Hasil analisis observasi yang diuraikan dapat disimpulkan bahwa model pembelajaran AIR pada mata kuliah Sejarah dan Filsafat Matematika dapat meningkatkan keaktifan mahasiswa dalam selama perkuliahan berlangsung dikarenakan model pembelajaran ini menuntut mahasiswa untuk aktif dalam menggunakan indranya dalam mendengarkan, menyimak dan presentasi dalam hal Auditory, sedangkan dalam proses keaktifan lainnya dalam menambahkan, bertanya dan menjawab dalam hal Intellectually dan mahasiswa bisa aktif juga dalam proses hasil evaluasi akhir dengan diberikan kuis yang mana ini dalam hal Repetition. Sehingga disetiap siklusnya keaktifan mahasiswa semakin meningkat dan baik dari hasil observasi dikelas. Hal ini sejalan dengan penelitian dari (Suwarman, 2017) bahwa model pembelajaran AIR dapat meningkatkan keatifan siswa setiap siklusinya. Model pembelajaran AIR bisa menjadi alternatif dosen atau guru dalam meningkatkan keaktifan siswa ataupun mahasiswa dikelas.

\section{KESIMPULAN}

Hasil analisis observasi yang diuraikan dapat disimpulkan bahwa model pembelajaran Auditory Intellectually Repetition (AIR) pada mata kuliah Sejarah dan Filsafat Matematika dapat meningkatkan keaktifan dalam menambahkan materi, bertanya, menjawab pertanyaan mahasiswa selama perkuliahan berlangsung. 


\section{REFERENSI}

Agustiana, E., Putra, F. G., \& Farida. (2018). Pengaruh Auditory, Intellectually, Repetition ( AIR) dengan Pendekatan Lesson Study terhadap Kemampuan Pemecahan Masalah Matematis. Desimal, 1(1), 1-6.

Arikunto, S. (2006). Prosedur Penelitian Suatu Tindakan Praktik. Jakarta: Rineka Cipta.

Dimyati, M. dan. (2013). Model-model pengajaran dan pembelajaran. Teaching and Educations, 1, 3.

Hamalik, O. (2011). Pengembangan Sumber Daya Manusia Manajemen Pelatihan Ketenagakerjaan Pendekatan Terpadu. In Proses Belajar Mengajar.

Inayah, S., Septian, A., \& Suwarman, R. F. (2020). Student Procedural Fluency in Numerical Method Subjects. Desimal: Jurnal Matematika, 3(1), 53-64. https://doi.org/10.24042/djm.v3i1.5316

Isna, R., \& Masykuri, M. (2018). The development of interactive multimedia based on auditory, intellectually, repetition in repetition algorithm learning to increase learning outcome The development of interactive multimedia based on auditory, intellectually, repetition in repetition. Journal Of Physics: Conference Series, $1013(1), 2-10$.

Maskur, R., Sumarno, Rahmawati, Y., Pradana, K., Syazali, M., Septian, A., \& Palupi, E. K. (2020). The effectiveness of problem based learning and aptitude treatment interaction in improving mathematical creative thinking skills on curriculum 2013. European Journal of Educational Research, 9(1), 375-383. https://doi.org/10.12973/eu-jer.9.1.375

Norjannah, S. (2015). Peraturan Menteri Riset, Teknologi, dan Pendidikan Tinggi Republik Indonesia Nomor 44 Tahun 2015. Permenristek, 151, 10-17. https://doi.org/10.1145/3132847.3132886

Sanjaya, W. (2010). Strategi Pembelajaran Berorientasi Standar Proses Pendidikan. System, Vol. 6, pp. 140-151.

Septian, A. (2017). Penerapan Geogebra untuk Meningkatkan Kemampuan Pemecahan Masalah Matematis Mahasiswa Program Studi Pendidikan Matematika Universitas Suryakancana. PRISMA, 6(2). https://doi.org/10.35194/jp.v6i2.212

Suharsimi;, A. (2013). Dasar-Dasar Evaluasi Pendidikan. Jakarta: Bumi Aksara, p. 168.

Sutarno, M. H., Rohendi, M. D., \& Putri, G. G. (2011). Pengaruh Kompetensi Guru Mata Pelajaran TIK Terhadap Motivasi dan Hasil Belajar Siswa. Jurnal Pengajaran Matematika Dan Ilmu Pengetahuan Alam, 16(2), 134. https://doi.org/10.18269/jpmipa.v16i2.268

Suwarman, R. F. (2017). Pengaruh Model Pembelajaran Auditory, Intellectually, Repetition (AIR) terhadap Peningkatan Pemecahan Masalah Matematis Siswa. PRISMA, 6(2). https://doi.org/10.35194/jp.v6i2.58 